\title{
Pengaruh Kualitas Pelayanan Terhadap Peningkatan Kepuasan Pelanggan Pada Hotel Bogor
}

\author{
Rani Kurniasari
}

Fakultas Ekonomi Dan Bisnis

Universitas Bina sarana Informatika

E-mail: rani.rku@bsi.ac.id

Cara Sitasi: Kurniasari, R. (2019). Pengaruh Kualitas Pelayanan Terhadap Peningkatan Kepuasan Pelanggan Pada Hotel Bogor. Widya Cipta, 3(1), 129-134.

\begin{abstract}
Excellent service quality is an important factor in increasing customer satisfaction. This study aims to determine the effect of service quality on customer satisfaction in Bogor hotels. Questionnaire calculation uses SPSS by testing the validity and reliability of each question item followed by a test of the correlation coefficient, determination coefficient and regression equation. The results of this study are that there is a significant influence on hotel customer satisfaction. SPSS calculation results obtained the determination coefficient of $95.7 \%$, which means that the effect of service quality on customer satisfaction is $95.7 \%$ and the remaining $4.3 \%$ is influenced by other factors. Correlation coefficients obtained results of 0.978 which means that the relationship between service quality and customer satisfaction is very strong. So from the results of the correlation coefficient obtained, it was concluded that HI was accepted which meant that there was a significant relationship between service quality and customer satisfaction. And based on the calculation of the regression equation obtained results of $Y=2.455+0.959 X$ which indicates that if the value of excellent service increases 1 , then the average value of customer satisfaction will increase by 0.959 .
\end{abstract}

Keywords: Service Quality, Customer Satisfaction

\section{PENDAHULUAN}

Pelayanan memiliki peran sangat penting dalam perusahaan yang bergerak di bidang jasa. Perhatian terhadap kepentingan pelanggan dengan cara melihat kebutuhan serta kepuasan atas pelayanan menjadi faktor kunci untuk keberhasilan usaha di tengah iklim persaingan yang semakin ketat. Menyadari pentingnya nilai sebuah kualitas layanan kepada pelanggan demi meningkatkan kepuasan pelanggan maka semakin membuat perusahaan semakin membuat perusahaan harus mengembangkan bisnis pada manajemen hubungan pelanggan yang baik.

Industri perhotelan adalah salah satu industri yang mengutamakan kualitas pelayanan. Saat ini industri hotel dituntut untuk dapat mengerti apa yang menjadi keinginan atau harapan sehingga kualitas pelayanan yang diberikan dapat memberikan kepuasan bagi konsumen. Kualitas pelayanan yang prima merupakan salah satu faktor penting dalam meningkatkan kepuasan pelanggan. Dengan mengetahui keinginan atau harapan dari konsumen yang setiap saat bisa berubah, maka kualitas pelayanan yang diberikan dapat disesuaikan dan ditingkatkan agar dapat meningkatkan kepuasan pelanggan. Peningkatan kepuasan pelanggan di harapkan dapat meningkatkan jumlah tamu yang datang.

Hotel di Bogor sangat banyak jumlahnya hal ini dapat dilihat dari data pada BPS kota bogor (Bogor, 2018) bahwa sejak tahun 2013-2016 dari 45 hotel bertambah menjadi 53 hotel. Para wisatawan lokal dan asing banyak yang menggunakan jasa hotel saat mereka mengadakan kegiatan atau wisata. Lokasi bogor yang sangat sejuk dan juga dengan berbagai tempat wisata menarik, menjadikan Bogor menjadi kota yang banyak dikunjungi, oleh karena itu penulis tertarik meneliti mengenai pengaruh dari kualitas pelayanan terhadap kepuasan dari salah satu hotel yang berlokasi di pusat kota Bogor.

Pelayanan prima menurut (Daryanto \& Setiabudi, 2014)"merupakan terjemahan istilah "excellent service" yang secara harfiah berarti pelayanan terbaik atau sangat baik. Disebut sangat baik atau terbaik karena sesuai dengan standar pelayanan yang berlaku atau dimiliki instansi pemberi pelayanan".

(Rahmayanty, 2013) mengemukakan bahwa: 
1. Layanan prima adalah pelayanan yang sangat baik dan melampaui harapan pelanggan.

2. Layanan prima adalah pelayanan yang memiliki ciri khas kualitas (quality nice).

3. Layanan prima adalah pelayanan dengan standar kualitas yang tinggi dan selalu mengikuti perkembangan kebutuhan pelanggan setiap saat, secara konsisten dan akurat (handal).

4. Layanan prima adalah pelayanan yang memenuhi kebutuhan praktis (practical needs) dan kebutuhan emosional (emotional needs) pelanggan.

Menurut (Suryani \& Sartika, 2018) Pelayanan pelanggan merupakan penunjang dalam memasarkan produk barang atau jasa yang menitik beratkan kepada upaya pendekatan, keyakinan dan kepuasan konsumen. Dengan pelayanan perusahaan dapat menciptakan kekhususan dalam menjalankan kegiatan usaha dari para pesaing yang menjual jasa yang sama.

Dalam riset nya ((Riyanto, 2018) menyatakan bahwa Hubungan antara kualitas pelayanan dengan kepuasan pelanggan sangat berpengaruh secara signifikan. Artinya bahwa pelayanan yang diberikan mampu meningkatkan kepuasan pelanggan secara positif.

Manfaat pelayanan prima menurut (Suratriadi dkk, 2018) "Pelayanan prima bermanfaat bagi upaya peningkatan kualitas pelayanan pemerintah kepada masyarakat sebagai pelanggan dan sebagai acuan pengembangan penyusunan standar pelayanan".

Jenis-jenis pelayanan prima menurut (Daryanto \& Setiabudi, 2014)dapat dibedakan menjadi tiga kelompok, yaitu:

1. Core Service

Core service adalah pelayanan yang ditawarkan kepada pelanggan, yang merupakan produk utamanya. Misalnya untuk hotel adalah penyediaan kamar dan untuk penerbangan adalah transportasi udara. Perusahaan mungkin mempunyai beberapa core service, misalnya perusahaan penerbangan menawarkan penerbangan dalam negeri dan penerbangan luar negeri.

2. Facilitating Service

Facilitating service adalah fasilitas pelayanan tambahan kepada pelanggan dan sifatnya wajib, misalnya pelayanan "front office" pada hotel atau pelayanan "check in" pada transportasi udara.

3. Supporting Service

Seperti pada facilitating service, supporting service merupakan pelayanan tambahan (pendukung) untuk meningkatkan nilai pelayanan atau untuk membedakan dengan pelayanan-pelayanan dari pihak "pesaingnya" dan bersifat tidak wajib. Misalnya restoran pada suatu hotel.

Sedangkan kepuasan pelanggan menurut (Tjiptono \& Chandra, 2016) yaitu "kata kepuasan (satisfaction) berasal dari bahasa latin "satis" (artinya cukup baik, memadai) dan "facio" (melakukan atau membuat). Kepuasan bisa diartikan sebagai "upaya pemenuhan sesuatu" atau "membuat sesuatu memadai".

Dan menurut Kotler dan Keller dalam (Riyanto, 2018) kepuasan pelanggan adalah "perasaan senang atau kecewa seseorang yang timbul karena membandingkan kinerja yang dipersepsikan terhadap ekspektasi mereka".

\section{METODOLOGI PENELITIAN}

Penelitian ini dilakukan dengan membahas mengenai populasi dan sampel yang diambil yaitu dengan menjelaskan uji validitas dan reliabilitas data kuesioner yang penulis gunakan. Kemudian hasil kuisioner ini diolah menggunakan SPSS (Statistical Product and service Solution) versi 21. Untuk mengetahui pengaruh dari kualitas pelayanan terhadap kepuasan pelanggan maka penulis menggunakan koefisien korelasi, koefisien determinasi dan persamaan regresi. Pada penelitian kali ini penulis menggunakan teknik simple random sampling atau pengambilan sampel secara acak dimana seluruh anggota populasi mempunyai kesempatan yang sama untuk dipilih menjadi responden. Populasi dari penelitian ini adalah ratarata dari jumlah pengunjung salah satu hotel besar di Bogor yang berkunjung pada tahun 2018 (januariapril 2018) yaitu sebanyak 262 orang. Pengambilan sampel pada penelitian ini menggunakan rumus slovin dengan taraf kesalahan 10\% (0.1) sehingga besar sampel yang diambil dalam penelitian ini 72 orang responden.

\section{HASIL DAN PEMBAHASAN}

\section{Uji Instrumen Penelitian}

Uji instrumen penelitian ini terdiri dari uji validitas dan uji reliabilitas. Uji instrumen ini digunakan untuk menguji data kuesioner yang digunakan apakah valid atau tidak dan reliabel atau tidak, sehingga data tersebut bisa dipakai untuk hasil penelitian berikutnya.

\section{a. Uji Validitas}

Uji validitas dilakukan untuk mengukur seberapa valid atau tidaknya kuesioner dari masingmasing variabel. Pengujian validitas dilakukan dengan membandingkan nilai $r$ hitung dengan $r$ Tabel. Berikut merupakan Tabel uji validitas variabel kualitas pelayanan $(\mathrm{X})$ : 
Tabel 1. Hasil Uji Validitas Variabel Kualitas Pelayanan (X)

\begin{tabular}{|c|c|c|c|c|}
\hline \multirow{16}{*}{ Kualitas Pelayanan } & Indikator & r hitung & \multirow[t]{8}{*}{$r$ table } & Keterangan \\
\hline & $\mathrm{X} 1$ & 0,632 & & Valid \\
\hline & $\mathrm{X} 2$ & 0,635 & & Valid \\
\hline & $\mathrm{X} 3$ & 0,632 & & Valid \\
\hline & $\mathrm{X} 4$ & 0,456 & & Valid \\
\hline & X5 & 0,467 & & Valid \\
\hline & $\mathrm{X} 6$ & 0,445 & & Valid \\
\hline & $\mathrm{X} 7$ & 0,526 & & Valid \\
\hline & $\mathrm{X} 8$ & 0,419 & \multirow[t]{8}{*}{0,232} & Valid \\
\hline & X9 & 0,358 & & Valid \\
\hline & $\mathrm{X} 10$ & 0,293 & & Valid \\
\hline & $\mathrm{X} 11$ & 0,513 & & Valid \\
\hline & $\mathrm{X} 12$ & 0,239 & & Valid \\
\hline & $\mathrm{X} 13$ & 0,533 & & Valid \\
\hline & X14 & 0,659 & & Valid \\
\hline & $\mathrm{X} 15$ & 0,522 & & Valid \\
\hline
\end{tabular}

Sumber: Data yang Diolah: 2018

Berdasarkan tabel $\mathrm{r}$ product moment taraf kesalahan $5 \%(0,05)$ dengan uji 2 (dua) sisi dengan jumlah data $(\mathrm{N})=72$ maka didapat nilai $\mathrm{r}$ Tabel adalah 0,232. Dari Tabel 1 dapat terlihat bahwa semua indikator nilai $r$ hitungnya lebih besar dari tabel $r$ dengan taraf kesalahan 5\% (0,05), maka dapat disimpulkan indikator kualitas pelayanan tersebut valid dan dapat digunakan untuk penelitian. Dan untuk hasil data kuesioner variabel kepuasan pelanggan (Y) dapat terlihat dengan tabel berikut:

Tabel 2. Hasil Uji Validitas Variabel Kepuasan Pelanggan (Y)

\begin{tabular}{|c|c|c|c|c|}
\hline \multirow{16}{*}{ Kepuasan Pelanggan } & Indikator & r hitung & \multirow[t]{8}{*}{$r$ tabel } & Keterangan \\
\hline & Y1 & 0,591 & & Valid \\
\hline & $\mathrm{Y} 2$ & 0,606 & & Valid \\
\hline & Y3 & 0,643 & & Valid \\
\hline & Y4 & 0,485 & & Valid \\
\hline & Y5 & 0,461 & & Valid \\
\hline & Y6 & 0,434 & & Valid \\
\hline & Y7 & 0,484 & & Valid \\
\hline & Y8 & 0,420 & \multirow[t]{8}{*}{0,232} & Valid \\
\hline & Y9 & 0,359 & & Valid \\
\hline & Y10 & 0,258 & & Valid \\
\hline & Y11 & 0,433 & & Valid \\
\hline & Y12 & 0,247 & & Valid \\
\hline & Y13 & 0,458 & & Valid \\
\hline & Y14 & 0,502 & & Valid \\
\hline & Y15 & 0,524 & & Valid \\
\hline
\end{tabular}

Sumber: Data yang Diolah: 2018

Berdasarkan Tabel $r$ product moment taraf kesalahan 5\% $(0,05)$ dengan uji 2 (dua) sisi dengan jumlah data $(\mathrm{N})=72$ maka didapat nilai $\mathrm{r}$ tabel adalah 0,232. Dari Tabel 2 dapat terlihat bahwa semua indikator nilai $r$ hitungnya lebih besar dari tabel $\mathrm{r}$ dengan taraf kesalahan 5\% $(0,05)$, maka dapat disimpulkan indikator kepuasan pelanggan tersebut valid dan dapat digunakan untuk penelitian.

\section{b. Uji Reliabilitas}

Uji reliabilitas digunakan untuk mengetahui apakah indikator yang dipakai untuk kuesioner dapat digunakan atau handal sebagai alat ukur tabel. Untuk menguji reliabel atau tidak, dapat dilihat dari nilai cronbach's alpha, jika lebih besar dari (>) 0,6 maka indikator atau kuesioner adalah reliabel. Berikut merupakan tabel hasil uji reliabilitas variabel $\mathrm{X}$ dan $\mathrm{Y}$ :

Tabel 3. Hasil Uji Reliabilitas Variabel X dan Y

\begin{tabular}{c|c|c|c}
\hline Variabel & $\begin{array}{c}\text { Cronbach's } \\
\text { Alpha }\end{array}$ & $\begin{array}{c}\text { Standard } \\
\text { Reliabilitas }\end{array}$ & Keterangan \\
\hline Kualitas Pelayanan (X) & 0,776 & 0,6 & Reliabel \\
Kepuasan Pelanggan (Y) & 0,732 & 0,6 & Reliabel \\
\hline
\end{tabular}

Sumber: Data yang Diolah: 2018 
Berdasarkan Tabel 3 diatas, terlihat bahwa variabel kualitas pelayanan (X) sebesar 0,776 dan variabel kepuasan pelanggan (Y) sebesar 0,732 yang berarti nilai cronbach's alpha lebih besar (>) dari 0,6, sehingga dapat disimpulkan indikator atau kuesioner yang digunakan, semua dinyatakan mempunyai reliabilitas sangat baik.

\section{Uji Koefisien Korelasi}

Untuk mengetahui seberapa besar hubungan antara variabel kualitas pelayanan terhadap kepuasan pelanggan, penulis menggunakan uji signifikasi product moment secara praktis, yang tidak perlu dihitung, tetapi langsung dikonsultasikan pada Tabel $\mathrm{r}$ product moment Dari Tabel $\mathrm{r}$ product moment dapat dilihat bahwa untuk $\mathrm{n}=72$, dengan taraf kesalahan 5\% (0,05), maka nilai $\mathrm{r}$ Tabel $=$ 0,232 . Ketentuannya bila $\mathrm{r}$ hitung lebih kecil daripada tabel, maka $\mathrm{H}_{0}$ diterima dan $\mathrm{H}_{1}$ ditolak. Tetapi sebaliknya bila $\mathrm{r}$ hitung lebih besar dari $\mathrm{r}$ tabel $(0,232)$. Dengan demikian $\mathrm{H}_{1}$ diterima dan $\mathrm{H}_{0}$ ditolak. Berdasarkan perhitungan koefisien korelasi menggunakan SPSS adalah:

Tabel 4. Correlations

\begin{tabular}{llrr}
\hline & & \multicolumn{1}{c}{$\begin{array}{c}\text { Kualitas } \\
\text { Pelayanan }\end{array}$} & \multicolumn{1}{c}{ Kepuasan_Pelanggan } \\
\hline \multirow{2}{*}{ Kualitas Pelayanan } & \multicolumn{1}{l}{ Pearson Correlation } & 1 &, $978^{* *}$ \\
\cline { 2 - 4 } & Sig. (2-tailed) & 72 &, 000 \\
\cline { 2 - 4 } Kepuasan_Pelanggan & $\mathrm{N}$ &, $978^{* *}$ & 72 \\
\hline \multirow{2}{*}{ Searson Correlation } & Sig. (2-tailed) &, 000 & 1 \\
\cline { 2 - 4 } & $\mathrm{N}$ & 72 & 72 \\
\hline
\end{tabular}

**. Correlation is significant at the 0.01 level (2-tailed).

Sumber: Data yang Diolah: 2018

Berdasarkan Tabel 4 diatas, terlihat bahwa nilai $\mathrm{R}$ sebesar 0,978 bernilai positif dan mendekati angka 1. Maka koefisien korelasi yang ditemukan termasuk pada kategori "sangat kuat". Jadi terdapat hubungan yang sangat kuat antara kualitas pelayanan dan kepuasan pelanggan. Dengan demikian semakin tinggi perusahaan menerapkan kualitas pelayanan kepada para pengguna jasa atau pelanggan maka akan semakin meningkat pula kepuasan pelanggan.

\section{Uji Koefisien Determinasi}

Selain uji koefisien korelasi (r) yang didapat, koefisien determinasi yang dihitung menggunakan SPSS adalah:

Tabel 5. Tabel Anova

\begin{tabular}{llrrrrr}
\multicolumn{7}{c}{ ANOVA $^{\mathbf{a}}$} \\
\hline Model & & Sum of Squares & Df & Mean Square & F & Sig. \\
\hline \multirow{3}{*}{1} & Regression & 1083,447 & 1 & 1083,447 & 1551,824 &, $000^{\mathrm{b}}$ \\
& Residual & 48,872 & 70 &, 698 & & \\
\cline { 2 - 7 } & Total & 1132,319 & 71 & & & \\
\hline
\end{tabular}

a. Dependent Variable: Kepuasan_Pelanggan

b. Predictors: (Constant), Kualitas_Pelayanan

\section{Sumber: Data yang Diolah: 2018}

$\mathrm{H}_{0} \quad$ : tidak adanya pengaruh antara kualitas pelayanan dengan kepuasan pelanggan.

$\mathrm{H}_{1} \quad$ : adanya pengaruh antara kualitas pelayanan dengan kepuasan pelanggan.
Berdasarkan Tabel 5 diatas, terlihat bahwa nilai Signifikan senilai $0,000<0,05$ maka keputusannya $\mathrm{H}_{1}$ diterima, dapat disimpulkan bahwa ada pengaruh yang signifikan antara kualitas pelayanan terhadap Kepuasan Pelanggan. 
Tabel 6. Tabel SPSS Determinasi

\begin{tabular}{|c|c|c|c|c|}
\hline \multicolumn{5}{|c|}{ Model Summary } \\
\hline Model & $\mathrm{R}$ & R Square & $\begin{array}{l}\text { Adjusted R } \\
\text { Square }\end{array}$ & Std. Error of the Estimate \\
\hline 1 &, $978^{\mathrm{a}}$ & ,957 & 956 & ,836 \\
\hline
\end{tabular}

Predictors: (Constant), Kualitas Pelayanan

Sumber: Data yang Diolah: 2018

Berdasarkan Tabel 6 diatas, terlihat bahwa nilai $\mathrm{R}$ Square sebesar 0,957 atau 95,7\% artinya kepuasan pelanggan dipengaruhi oleh kualitas pelayanan sebesar $95,7 \%$ sisanya sebesar $4,3 \%$ dipengaruhi oleh faktor lain.

\section{Uji Persamaan Regresi}

Analisis regresi digunakan untuk memprediksi seberapa jumlah nilai variabel Y jika nilai variabel $\mathrm{X}$ dimanipulasi atau diubah-ubah Berikut perhitungan persamaan regresi berdasarkan SPSS:

Tabel 7. Tabel SPSS Persamaan Regresi

\begin{tabular}{|c|c|c|c|c|c|c|}
\hline \multicolumn{7}{|c|}{ Coefficients $^{\mathrm{a}}$} \\
\hline \multirow{2}{*}{\multicolumn{2}{|c|}{ Model }} & \multicolumn{2}{|c|}{ Unstandardized Coefficients } & \multirow{2}{*}{$\begin{array}{c}\begin{array}{c}\text { Standardized } \\
\text { Coefficients }\end{array} \\
\text { Beta } \\
\end{array}$} & \multirow[t]{2}{*}{$\mathrm{t}$} & \multirow[t]{2}{*}{ Sig. } \\
\hline & & $\mathrm{B}$ & Std. Error & & & \\
\hline \multirow{2}{*}{1} & (Constant) & 2,455 & 1,625 & & 1,511 &, 135 \\
\hline & Kualitas Pelayanan & ,959 &, 024 & ,978 & 39,393 &, 000 \\
\hline
\end{tabular}

a. Dependent Variable: Kepuasan_Pelanggan

Sumber: Data yang Diolah: 2018

Berdasarkan Tabel 7 diatas, pada hasil persamaan regresi untuk mengetahui angka konstan dan uji hipotesis signifikansi uji koefisien regresi. Oleh karena itu, persamaan regresinya menjadi $\mathrm{Y}=$ $2,455+0,959 X$. Angka konstan dari unstandardized coefficient sebesar 2,455. Angka ini berupa angka konstan yang bermakna bahwa besarnya kepuasan pelanggan saat nilai X (Kualitas Pelayanan) akan sebesar 2,455. Angka tersebut mempunyai arti bahwa setiap penambahan 1 kualitas pelayanan, kepuasan pelanggan akan meningkat sebesar 0,959X. Sebaliknya jika ini negatif (-), berlaku penurunan pada kepuasan pelanggan.

\section{KESIMPULAN}

Berdasarkan hasil penelitian, maka penulis mengambil kesimpulan tentang pengaruh kualitas pelayanan terhadap kepuasan pelanggan pada Hotel Bogor sebagai berikut:

1. Berdasarkan perhitungan koefisien determinasi diperoleh hasil yang berarti menunjukkan pengaruh kualitas pelayanan terhadap kepuasan pelanggan sebesar $95,7 \%$ dan sisanya $4,3 \%$ dipengaruhi oleh faktor-faktor lainnya.

2. Berdasarkan perhitungan koefisien korelasi diperoleh hasil sebesar 0,978 yang berarti hubungan antar kualitas pelayanan dan kepuasan pelanggan adalah "sangat kuat". Maka dari hasil koefisien korelasi yang didapat, disimpulkan bahwa adanya hubungan yang signifikan antara kualitas pelayanan dan kepuasan pelanggan. Dan berdasarkan perhitungan persamaan regresi diperoleh hasil sebesar $\mathrm{Y}=2,455+0,959 \mathrm{X}$.

\section{REFERENSI}

Bogor, B. P. S. K. (2018). Badan Pusat Statistik Kota Bogor. Retrieved from bogorkota.bps.go.id

Daryanto, \& Setiabudi, I. (2014). KONSUMEN dan PELAYANAN PRIMA. Yogyakarta: Gava Media.

Rahmayanty, N. (2013). Manajemen Pelayanan Prima. Yogyakarta: Graha Ilmu.

Riyanto, A. (2018). Ecodemica. Jurnal Ecodemica: Jurnal Ekonomi, Manajemen, Dan Bisnis, 2(1), 117-124. Retrieved from https://ejournal.bsi.ac.id/ejurnal/index.php/eco demica/article/view/2911/pdf

Suratriadi, P., ... W. N.-M., \& 2018, undefined. (2018). Pengaruh Pelayanan Prima Terhadap Kepuasan Pelanggan Pada Pt. Baraya Travel Cabang Jatiwaringin. Journal.StieKusumanegara.Ac.Id, 1(1), 171-180.

Suryani, D., \& Sartika, R. (2018). Pengaruh Pelayanan Customer Service Representative 
Terhadap Kepuasan Pelanggan Pada PT Bank Mandiri (PERSERO) Tbk Cabang Kalibata Jakarta. Managerial, 1(1), 51-60. Retrieved from http://journal.stiekusumanegara.ac.id/index.php/managerial/arti cle/view/17

Tjiptono, F., \& Chandra, G. (2016). Service, Quality dan Satisfaction. Yogyakarta: CV. Andi Offset.

\section{PROFIL PENULIS}

Saya Menyelesaikan Jenjang S1 di Universitas Gunadarma, kemudian melanjutkan pada program Pasca Sarjana Universitas Gunadarma yang berhasil di selesaikan Pada tahun 2007. Saya mulai mengajar di UBSI sejak tahun 2009. 